\title{
PERCEPTION OF SOCIAL
}

VARIABLES RELATED TO

ALLOPHONES OF TAPS AND

TRILLS: A PRELIMINARY STUDY

WITH COSTA RICAN MIDDLE

CLASS SPEAKERS

\author{
Mariela A. PORRAS-CHAVERRI (D $\boldsymbol{D}$ \\ University of Costa Rica (UCR)
}

open Access

EDITORS

Raquel POCASANGRE-FONSECA (iD

University of Costa Rica (UCR)

- Miguel Oliveira, Jr. (UFAL)

- René Almeida (UFS)

REVIEWERS

- Elisa Battisti (UFRGS)

- Matt Dearstyne (Georgetown)

\section{ABOUT THE AUTHORS}

- Mariela A. Porras-Chaverri

Conceptualization, Investigation,

Methodology, Writing-Original Draft.

- Raquel Pocasangre-Fonseca

Conceptualization, Investigation,

Methodology, Writing- Review

and Editing.

\section{DATES}

- Received: 09/01/2021

- Accepted: 10/18/2021

- Published: 12/14/2021

\section{HOW TO CITE}

PORRAS-CHAVERRI, Mariela A.; POCASANGRE-FONSECA, Raquel (2021). Perception of Social Variables Related to Allophones of Taps and Trills: A Preliminary Study with Costa Rican Middle Class Speakers.

Cadernos de Linguística, v. 2, n. 1, e593

\section{ABSTRACT}

This work presents preliminary research into determining listener perception of socioeconomic class and educational level based on the allophones of the alveolar tap /r/ and trill/r/ found in Costa Rican Spanish. The population of speakers is male and female professionals living in the Greater Metropolitan Area (GAM) [23-46 years] but originally from different areas in the country. Data were collected through written questionnaires and recordings. In the first questionnaire the speakers were asked about their origin, self-perception of their variant and negative linguistic experiences related to their speech. They were also asked to read a series of guises. In the second questionnaire each participant listened to the readings of another speaker. Members of each speaker-listener pair were unknown to one another, and no additional social information was provided to the listeners. Each listener was asked to estimate the socioeconomic and educational levels of the speaker. In the reading of sentences, tap and retroflex realizations of / $\mathbf{r} /$ were observed before nasals, in all other environments, tap was the variant 
present. In the case of $/ r /$, approximant, fricative, retroflex and trill realizations were observed at various locations. A larger number of variants was observed in the answering of questions than in the reading of sentences. All speakers showed allophonic realizations to the alveolar tap and alveolar trills consistent with those found in Costa Rican middle or upper class. Most speakers were perceived as having secondary education as the highest educational level. This perception does not seem to be related to gender but may be related to perception of the speaker's voice as that of a teenager, but no data on age-perception was collected in this study so this relationship could not be clarified. Future developments of this study should consider the influence of social information in listener perception.

\section{RESUMEN}

Este trabajo presenta una investigación preliminar para determinar la percepción del oyente de clase socioeconómica y nivel educativo de un hablante con base en los alófonos de la vibrante simple /r/ y la vibrante múltiple / $r$ / encontrados en el español costarricense. La población de hablantes son hombres y mujeres profesionales residentes en el Gran Área Metropolitana (GAM) [23-46 años] pero originarios de diferentes áreas del país. Los datos se recopilaron mediante cuestionarios escritos y grabaciones. En el primer cuestionario se preguntó a los hablantes sobre su origen, la autopercepción de su habla y sobre experiencias lingüísticas negativas relacionadas con su habla. También se les pidió que leyeran una serie de frases. En el segundo cuestionario cada participante escuchó las lecturas de otro hablante. Los miembros de cada pareja de hablante-oyente eran desconocidos entre sí, y no se proporcionó información social adicional a los oyentes. Se pidió a cada oyente que estimara el nivel socioeconómico y educativo del hablante. En la lectura de oraciones, las realizaciones vibrante y retrofleja de /r/ se observaron antes de nasales, en todos los demás entornos, vibrante fue la variante presente. En el caso de /r/, se observaron realizaciones aproximante, fricativa, retrofleja y vibrante en varias posiciones. Se observó un mayor número de variantes en la respuesta a preguntas que en la lectura de frases. Todos los hablantes mostraron realizaciones alofónicas de la vibrante simple y vibrante múltiple consistentes con los encontrados en la clase media o alta costarricense. Se percibió que la mayoría de los 
hablantes tenían educación secundaria como el nivel educativo más alto. Esta percepción no parece estar relacionada con el género, pero puede estar relacionada con la percepción de la voz del hablante como la de un adolescente, sin embargo, en este estudio no se recopilaron datos sobre la percepción de la edad por lo que esta relación no se pudo esclarecer. Los desarrollos futuros de este estudio deben considerar la influencia de la información social en la percepción del oyente.

\section{KEYWORDS}

Costa Rican Speech; Social Perceptions; Allophones;

Alveolar Tap and Alveolar Trill.

\section{PALABRAS CLAVES}

Habla Costarricense; Percepciones Sociales; Alófonos;

Vibrantes Simple y Múltiple Alveolares. 


\section{INTRODUCTION}

Migration processes and the geography of Costa Rica have given rise to a complex dialect reality in this country. There are areas within the country that are geographically separated, but that share phonetic features (QUESADA PACHECO, 1991; 2013).

A particular set of variables of interest correspond to the alveolar trill $/ r /$ and the alveolar tap /r/. These rhotics present several allophones, some associated with different localities and phonological environments. Likewise, social processes and the influence of academic authority figures and the press have led to the stigmatization of some of these variants. This is the case of rural speech, the voiceless alveolar approximant allophone of the alveolar tap, and the voiced alveolar approximant of the alveolar trill. (QUESADA PACHECO, 2000).

In this work ${ }^{1}$ we explore, in a preliminary way, the perception of social class and educational level that may be associated with different allophones of the rhotics. For the purposes of this work, perception is understood as the impression that a listener has regarding a recording of an unknown speakers' socioeconomic class and educational level, in the absence of additional social clues. Additionally, self-perception refers to the impression that a speaker has that their speech reflects their socioeconomic class.

The sample of speakers used in this study are all middle-class Costa Rican professionals, and inhabitants of the Central Valley, although they come from different regions of the country. Unlike in other previous studies of listener perception (CAMPBELLKIBLER 2006; NIEDZIELSKI 1999), the listeners in our study were not provided with information regarding the social characteristics of the speakers.

We consider whether the different allophones of the alveolar tap and alveolar trill may be related to different sociocultural perceptions. In particular, our hypothesis is that the use of the voiceless alveolar approximant as an allophone of the tap and the assibilated realizations of the trill are related to listener perceptions of the speaker as belonging to a lower socioeconomic class or having lower educational level.

\section{THEORETICAL FRAMEWORK}

This work focuses on the alveolar tap / $\mathbf{r} /$ and trill / $r /$, as well as their various allophones within Costa Rican speech. This study is focused on the strings of segments that contain

1 An earlier version of this work was presented at the Linguistweets conference in 2020 and its presentation can be found on Twitter using the \#It0115 hashtag in the @porraschaver profile. 
the alveolar tap in combination with other consonants, as is the case with the segment $/ \mathrm{tr} /$ and $/ \mathrm{dr} /$.

According to the work of Quesada Pacheco (1996) the alveolar tap has four allophones:

1. Voiced alveolar tap [r]: this allophone is found across all regions of the country.

2. Voiceless alveolar approximant [ı]: this allophone has been described by Quesada Pacheco both as voiceless alveolar fricative (QUESADA PACHECO 1996) and as voiceless prepalatal fricative (QUESADA PACHECO 2000). However, the symbols used in both works suggest that the allophone corresponds to an approximant in the current IPA terminology. It is found before /s/and in the string of segments /tr/. This allophone is found in the Central Valley, although it is currently receding, and it is stigmatized by the urban youth population (QUESADA PACHECO 2000).

3. Voiced alveolar approximant [u]: this allophone is described as voiced alveolar fricative in (QUESADA PACHECO 1996), although the symbol used corresponds to the alveolar approximant. It is found in complementary distribution with [ـ] $]$.

4. Voiced retroflex tap [r]: found in the Central Valley and to a smaller extent in the Northwest, South and Atlantic regions of the country.

An additional variant of the alveolar tap described by Quesada Pacheco (1996) corresponds to the elision of / $\mathbf{r} /$ before enclitic pronouns (except in the case of the pronoun -te). Elision of the alveolar tap in the infinitive before enclitic pronouns is considered a stereotypical element of rural speech. Even the school system and the media fight this variant (QUESADA PACHECO, 2000).

In the case of the alveolar trill /r/, Quesada Pacheco (1996) describes the following allophones:

1. Voiced alveolar trill [r]: found in all regions of the country and more frequently in the northwest, north, Atlantic, and South Pacific regions.

2. Voiced alveolar approximant [ı]: this allophone is described by Quesada Pacheco (1996) as voiced alveolar tense fricative, however, the symbol used corresponds to the current voiced alveolar approximant. This is the most common allophone of / $r /$ in Costa Rica.

3. Voiced alveolar affricate [dג]: this allophone can be found after pause, nasal or lateral.

4. Voiceless alveolar approximant [ı]]: found only in final position. This allophone was described by Quesada Pacheco (1996) as voiceless alveolar fricative.

5. Voiced retroflex approximant [A]: found more frequently in the young population. 
6. Voiced uvular trill [R]: found only in the Puriscal region and stigmatized by the educational system

Other authors have studied the phonetic variation of rhotics in Costa Rican speech, particularly in San José (CALVO SHADID, 1995; CALVO SHADID; PORTILLA CHAVES, 1998; VÁSQUEZ CARRANZA 2006), and have observed more allophones than those described above. However, we consider that the work by Quesada Pacheco (1996) provides a summarized overview of the allophones of rhotics present in Costa Rican speech, as it considers speakers from different regions of the country.

A previous study by Calvo Shadid and Castillo Rivas (2014) has shown that Costa Rican speakers in the Central Valley perceive the speech variety from the Central Valley as distinct from that of the other regions in the country.

The perception of socioeconomic characteristics of a speaker based on audio samples has been found to be dependent on social information regarding the speakers (NIEDZIELSKI 1999; CAMPBELL-KIBLER, 2006). A study by Niedzielsky (1999), done on English language speakers in Canada, showed that listeners make use of social information, including stereotypes, when considering their perception of a speaker's variety. The aforementioned study also showed that speakers can provide inaccurate assessments of their own variety. Due to the possible influence of social information on the perceptions of speakers, Niedzielsky concludes that research in speech perception and language change must take this effect into account.

The work of Campbell-Kibler (2006), although focused on the variable (ING) in English pronunciation, further showed that the perception of listeners is based on social and linguistic contexts. The social information available is connected in various ways by the different listeners and used to construct inferences about the speakers. These inferences may include aspects such as origin, region, education, and even sexual orientation of the speaker. Even a single variable, such as (ING), is linked to a complex network of social meanings. As a consequence, studies must take into consideration that social information available to listeners plays a crucial role in determining listener perception.

\section{METHODOLOGY}

The population of interest in this study corresponded to a group of professionals living in the Greater Metropolitan Area (Gran Area Metropolitana, GAM) originally from both this area and from other regions of the country. The study population consisted of 12 people aged between 23 and 46 years. Eight people were women and four were men. The details of this population are found in Table 1. The sample was composed of speakers available to 
the researchers. All speakers are identified with the H\# label, where \# corresponds to a sequential identification number arbitrarily assigned to each participant.

All participants provided informed consent to participate in this study. They were volunteers and did not receive any form of payment for their participation in this work.

\begin{tabular}{|c|c|c|c|c|c|c|c|c|}
\hline Informant & Gender & Profession & Age & Origin & $\begin{array}{l}\text { Years } \\
\text { living in } \\
G A M \\
\end{array}$ & Primary & $\begin{array}{l}\text { High } \\
\text { school }\end{array}$ & University \\
\hline $\mathrm{H} 1$ & Female & Economist & 33 & San José & 30 & Private & Private & Private \\
\hline $\mathrm{H} 2$ & Female & Teacher & 36 & Pavas & 36 & Private & Private & Mixed \\
\hline H3 & Female & Teacher & 46 & Puriscal & 5.5 & Public & Public & Public \\
\hline $\mathrm{H} 4$ & Female & Teacher & 43 & San José & 33 & Public & Public & Public \\
\hline H5 & Female & Coach & 26 & $\begin{array}{l}\text { San } \\
\text { Rafael } \\
\text { Alajuela }\end{array}$ & 26 & Public & Public & Public \\
\hline $\mathrm{H} 6$ & Male & Administrator & 43 & $\begin{array}{l}\text { Guayabo } \\
\text { de Mora }\end{array}$ & 43 & Public & Public & Mixed \\
\hline $\mathrm{H} 7$ & Female & Economist & 37 & Hatillo & 37 & Public & Private & Public \\
\hline H8 & Female & Physiotherapist & 36 & Hatillo & 36 & Public & Private & Public \\
\hline H9 & Female & Administrator & 36 & Pavas & 25 & Public & Mixed & Private \\
\hline $\mathrm{H} 10$ & Male & Sociologist & 26 & Turrialba & $\begin{array}{l}6 \\
\text { months }\end{array}$ & Public & Public & Public \\
\hline $\mathrm{H} 11$ & Male & Physiotherapist & 2. 3 & Turrialba & 4 & Private & Private & Private \\
\hline $\mathrm{H} 12$ & Male & $\begin{array}{l}\text { Political } \\
\text { scientist }\end{array}$ & 28 & Turrialba & 1 & Public & Public & Public \\
\hline
\end{tabular}

Table 1. Study population.

The data collection was carried out in two questionnaires. The questionnaires used are included in their entirety as part of the supplementary documentation to this work.

The purpose of the first questionnaire was to serve as an instrument to identify the allophonic variants of the alveolar tap and trill used by the studied population. It also sought to identify the self-perception of the participants to their own variety. In addition, it provided audio samples of phrases with alveolar taps and trills in different environments (as summarized in Table 2), as well as audio of their speech in the answering of the questions. Additionally, a question was included to identify whether participants have had a negative experience regarding how other people perceive their speech.

The initial questionnaire was divided into four parts: 
a. Technical data sheet to collect personal information from the participant.

b. Evaluation of the self-perception that the subject has regarding their own speech.

c. Description of negative sociolinguistic experiences of the participant.

d. Reading of sentences (guises) containing / $\mathbf{r} /$ and $/ r /$ in different positions.

\begin{tabular}{|c|c|c|c|}
\hline Segment & Number of occurrences & Environments & Examples \\
\hline$|r|$ & 9 & initial & robot \\
\hline $\mid \mathbf{r} /$ & 7 & intervocalic (5); end (2) & será \\
\hline$/ \mathrm{tr} /$ & 6 & initial (4); intervocalic (2) & tranquilo, astro \\
\hline$/ \mathrm{d} r /$ & 2 & $\begin{array}{l}\text { intervocalic; between } \\
\text { nasal and vowel }\end{array}$ & pedrería, Alejandro \\
\hline /pr/ & 2 & $\begin{array}{l}\text { initial; between nasal and } \\
\text { vowel }\end{array}$ & principito, compraron \\
\hline /br/ & 3 & $\begin{array}{l}\text { initial; intervocalic; } \\
\text { between nasal and vowel }\end{array}$ & brotan, obra, sembró \\
\hline$/ \mathbf{r} /+\operatorname{nasal}(/ \mathrm{m} /, / \mathrm{n} /)$ & 4 & after vowel & carne \\
\hline /rt/ & 1 & intervocalic & descubierto \\
\hline
\end{tabular}

Table 2. Occurrence of the allophones of interest in the reading task.

The second questionnaire was sent two weeks after the first. In this questionnaire the participants were instructed to listen to one of the audios generated by other participants reading the sentences. The speaker-listener pairs were assigned arbitrarily. Members of each pair were not aware of the geographic origin, education level nor socioeconomic group of one another. The speakers were also asked to answer three single choice questions. The questions were intended to determine the perception that each participant had of the corresponding speaker in the following categories:

a. Speech is characteristic of the GAM.

b. Education level.

c. Socioeconomic group.

Each of the categories is associated with a scale, as shown in the supplementary documentation. All responses to the first questionnaire were received as audio recordings via WhatsApp (FACEBOOK INC., 2020). The responses to the second questionnaire were received as WhatsApp images where the desired option was marked. 
The realizations observed in sentence readings were classified as assibilated (Asi), approximant (Apr), fricative (Fri), retroflex (Ret), tap (Tap) or trill (Tri) according to their phonetic features via auditory coding by a single coder. The use of a single coder is a limitation of this study, as it does not consider possible differences across coders (HESELWOOD; PLUG; TICKLE, 2008).

\section{RESULTS AND DISCUSSION}

In the sentence reading task, all speakers performed the alveolar tap as [r] in the intervocalic and final locations, as well as in the group [rt]. Similarly, it was realized as an alveolar tap in the context of the groups [tr], [dr] and [br]. Most of the speakers, except for $\mathrm{H} 1$, performed the group [pr] as tap. In the case of $\mathrm{H} 1$, one of its realizations was perceived by the coder as a fricative, although the coder considered it to be very close to a tap. Despite the lack of acoustical analysis to determine fricative noise, it was decided to code this instance as a fricative to show the slight variation in this case with respect to clearer realizations of the tap.

The realizations of the alveolar tap in the pre-nasal environment showed greater variability, as shown in Table 3. The tap allophone was most common; all the speakers presented at least one case with this variant.

\begin{tabular}{lllllllllllll}
\hline Variant & $\mathrm{H} 1$ & $\mathrm{H} 2$ & $\mathrm{H} 3$ & $\mathrm{H} 4$ & $\mathrm{H} 5$ & $\mathrm{H} 6$ & $\mathrm{H} 7$ & $\mathrm{H} 8$ & $\mathrm{H} 9$ & $\mathrm{H} 10$ & $\mathrm{H} 11$ & $\mathrm{H} 12$ \\
\hline $\begin{array}{l}\text { tap } \\
{[\mathrm{r}]}\end{array}$ & 1 & 1 & 2 & 4 & 4 & 2 & 1 & 4 & 3 & 4 & 4 & 4 \\
$\begin{array}{l}\text { retroflex } \\
{[\mathrm{r}]}\end{array}$ & 3 & 3 & 2 & 0 & 0 & 2 & 3 & 0 & 1 & 0 & 0 & 0 \\
\hline
\end{tabular}

Table 3. Distribution of observed variants of the alveolar tap located before nasal in sentence readings. The predominant variant, when one was found, is shown in bold.

In the case of the alveolar trill, the observed variants corresponded to trill [r], approximant [ג], fricative [ı] and retroflex [r]. The distribution of the variants for each speaker is shown in Table 4. No occurrences of the assibilated variant [ı] were found in the reading of the sentences. For the most part, the speakers maintained a single variant throughout all the sentences. In the case of the speakers who showed several variants, at least one was considered predominant over the others and was present in more than half of the occurrences. 


\begin{tabular}{|c|c|c|c|c|c|c|c|c|c|c|c|c|}
\hline Variant & $\mathrm{H} 1$ & $\mathrm{H} 2$ & H3 & $\mathrm{H} 4$ & H5 & $\mathrm{H} 6$ & $\mathrm{H} 7$ & H8 & $\mathrm{H} 9$ & $\mathrm{H} 10$ & $\mathrm{H} 11$ & $\mathrm{H} 12$ \\
\hline $\begin{array}{l}\text { trill } \\
{[r]}\end{array}$ & & - & - & - & 6 & - & - & - & 1 & 1 & - & 3 \\
\hline $\begin{array}{l}\text { fricative } \\
{[1]}\end{array}$ & 9 & - & 9 & 9 & 2 & 9 & 6 & - & - & - & - & 1 \\
\hline $\begin{array}{l}\text { approximant } \\
{[\Lambda]}\end{array}$ & - & 9 & - & - & 1 & - & - & 9 & 7 & 8 & 9 & 5 \\
\hline $\begin{array}{l}\text { retroflex } \\
{[\mathrm{r}]}\end{array}$ & - & - & - & - & - & - & 3 & - & 1 & - & - & - \\
\hline
\end{tabular}

Table 4. Distribution of observed variants of the alveolar trill during reading of sentences. The predominant variant, when one was found, is shown in bold.

The variants observed for each speaker in the audios answering the questions are detailed in Table 5. Due to variation in the number of occurrences and variant location for each speaker it is not possible to make a comparative distribution, such as the ones shown in Tables 3 and 4. No instances of elision were found across this study.

\begin{tabular}{|c|c|c|c|c|c|c|c|c|c|c|c|c|}
\hline Allophones: & $\mathrm{H} 1$ & $\mathrm{H} 2$ & H3 & $\mathrm{H} 4$ & $\mathrm{H} 5$ & $\mathrm{H} 6$ & $\mathrm{H} 7$ & $\mathrm{H} 8$ & H9 & $\mathrm{H} 10$ & $\mathrm{H} 11$ & $\mathrm{H} 12$ \\
\hline $\begin{array}{l}\text { Alveolar tap } \\
\mid \mathbf{r} /\end{array}$ & Tap & Tap & $\begin{array}{l}\text { Apr } \\
\text { Asi } \\
\text { Ret } \\
\text { Tap }\end{array}$ & Tap & $\begin{array}{l}\text { Asi } \\
\text { Tap }\end{array}$ & $\begin{array}{l}\text { Asi } \\
\text { Tap }\end{array}$ & $\begin{array}{l}\text { Fri } \\
\text { Ret }\end{array}$ & Apr & AprRet & Apr & Apr & $\begin{array}{l}\text { Apr } \\
\text { Fri }\end{array}$ \\
\hline $\begin{array}{l}\text { Alveolar trill } \\
|r|\end{array}$ & Fri & $\begin{array}{l}\text { Apr } \\
\text { Fri }\end{array}$ & $\begin{array}{l}\text { Apr } \\
\text { Fri }\end{array}$ & Fri & $\begin{array}{l}\text { Apr } \\
\text { Asi } \\
\text { Tri }\end{array}$ & Fri & $\begin{array}{l}\text { Fri } \\
\text { Ret }\end{array}$ & Apr & $\begin{array}{l}\text { Fri } \\
\text { Ret }\end{array}$ & $\begin{array}{l}\text { Apr } \\
\text { Fri }\end{array}$ & $\begin{array}{l}\text { Apr } \\
\text { Fri }\end{array}$ & $\begin{array}{l}\text { Apr } \\
\text { Fri }\end{array}$ \\
\hline
\end{tabular}

Table 5. Allophone variants observed in the answering of questions.

A comparison of the variants summarized in Tables 3, 4 and 5 shows that most of the speakers showed consistency in their use of the different allophones (Table 6). Across most speakers, the variants observed in the reading of the sentences were also present in the answering of questions. In general, more variants were observed in the answering of questions than in the reading of sentences (Table 6). 


\begin{tabular}{|c|c|c|c|c|}
\hline & Allophones of /r/ & & Allophones of $/ r /$ & \\
\hline Speaker & $\begin{array}{l}\text { Reading of } \\
\text { sentences }\end{array}$ & $\begin{array}{l}\text { Answering of } \\
\text { questions }\end{array}$ & $\begin{array}{l}\text { Reading of } \\
\text { sentences }\end{array}$ & $\begin{array}{l}\text { Answering of } \\
\text { questions }\end{array}$ \\
\hline $\mathrm{H} 1$ & $\begin{array}{l}\text { Ret } \\
\text { Tap }\end{array}$ & Tap & Fri & Fri \\
\hline $\mathrm{H} 2$ & $\begin{array}{l}\text { Ret } \\
\text { Tap }\end{array}$ & Tap & Apr & $\begin{array}{l}\text { Apr } \\
\text { Fri }\end{array}$ \\
\hline H3 & $\begin{array}{l}\text { Ret } \\
\text { Tap }\end{array}$ & $\begin{array}{l}\text { Apr } \\
\text { Asi } \\
\text { Ret } \\
\text { Tap }\end{array}$ & Fri & $\begin{array}{l}\text { Apr } \\
\text { Fri }\end{array}$ \\
\hline $\mathrm{H} 4$ & Tap & Tap & Fri & Fri \\
\hline H5 & Tap & $\begin{array}{l}\text { Asi } \\
\text { Tap }\end{array}$ & $\begin{array}{l}\text { Apr } \\
\text { Fri } \\
\text { Tri }\end{array}$ & $\begin{array}{l}\text { Apr } \\
\text { Asi } \\
\text { Tri }\end{array}$ \\
\hline $\mathrm{H} 6$ & $\begin{array}{l}\text { Ret } \\
\text { Tap }\end{array}$ & $\begin{array}{l}\text { Asi } \\
\text { Tap }\end{array}$ & Fri & Fri \\
\hline $\mathrm{H} 7$ & $\begin{array}{l}\text { Ret } \\
\text { Tap }\end{array}$ & $\begin{array}{l}\text { Fri } \\
\text { Ret }\end{array}$ & $\begin{array}{l}\text { Fri } \\
\text { Ret }\end{array}$ & $\begin{array}{l}\text { Fri } \\
\text { Ret }\end{array}$ \\
\hline H8 & Tap & Apr & Apr & Apr \\
\hline H9 & $\begin{array}{l}\text { Ret } \\
\text { Tap }\end{array}$ & $\begin{array}{l}\text { Apr } \\
\text { Ret }\end{array}$ & $\begin{array}{l}\text { Apr } \\
\text { Ret } \\
\text { Tri }\end{array}$ & $\begin{array}{l}\text { Fri } \\
\text { Ret }\end{array}$ \\
\hline $\mathrm{H} 10$ & Tap & Apr & $\begin{array}{l}\text { Apr } \\
\text { Tri }\end{array}$ & $\begin{array}{l}\text { Apr } \\
\text { Fri }\end{array}$ \\
\hline $\mathrm{H} 11$ & Tap & Apr & Apr & $\begin{array}{l}\text { Apr } \\
\text { Fri }\end{array}$ \\
\hline $\mathrm{H} 12$ & Tap & $\begin{array}{l}\text { Apr } \\
\text { Fri }\end{array}$ & $\begin{array}{l}\text { Apr } \\
\text { Fri } \\
\text { Tri }\end{array}$ & $\begin{array}{l}\text { Apr } \\
\text { Fri }\end{array}$ \\
\hline
\end{tabular}

Table 6. Summary of variants observed in reading of sentences and answering of questions. 
Table 7 shows a summary of the reports from the speakers of experiences related to their speech and their self-perception regarding their own speech. Most of the speakers considered that their own speech reflects a GAM middle class status ( 9 out of 12 speakers).

The speakers reported an assortment of experiences related to their speech: differences in the pronunciation of words, speed of speech, perception of the variety as foreign or from a different region and perception of a different socioeconomic status.

Other experiences reported by the speakers are related to the perception of the speech variety by non-Costa Ricans or were related to lexical or idiomatic differences. These experiences were considered outside the scope of this work because their origin is not phonetic.

Although in the questionnaire the were asked to include negative incidents, several of the speakers included experiences that they did not consider negative. It should be noted that even if the speakers themselves do not perceive the incidents as negative, the incidents may still correspond to instances of negative linguistic attitudes.

\begin{tabular}{|c|c|c|c|}
\hline Informant & $\begin{array}{l}\text { Does your speech } \\
\text { reflect the middle } \\
\text { class of the GAM? }\end{array}$ & Experiences due to their way of speaking & Observations \\
\hline $\mathrm{H} 1$ & Yes & $\begin{array}{l}\text { - Perception of pronunciation [r] by other } \\
\text { Latin } \\
\text { Americans (Colombians) }\end{array}$ & $X$ \\
\hline $\mathrm{H} 2$ & Yes & $\begin{array}{l}\text { - Derogatory perception of elision of syllables } \\
\text { (entonces as [tons]) } \\
\text { - Perception of higher socioeconomic status }\end{array}$ & $x$ \\
\hline H3 & Yes & $\begin{array}{l}\text { - They did not understand the meaning of } \\
\text { some } \\
\text { words in another region (Puntarenas) }\end{array}$ & $\begin{array}{l}\text { Does not consider } \\
\text { it a negative } \\
\text { experience }\end{array}$ \\
\hline $\mathrm{H} 4$ & No & - Speech speed perception & $x$ \\
\hline H5 & Yes & - Differences in the pronunciation of words & $\begin{array}{l}\text { Does not consider } \\
\text { it a negative } \\
\text { experience }\end{array}$ \\
\hline H6 & Yes & $\begin{array}{l}\text { - Perception of pronunciation }[r] \text { by other } \\
\text { Latin } \\
\text { Americans (Venezuelans) }\end{array}$ & $\begin{array}{l}\text { Does not consider } \\
\text { it a negative } \\
\text { experience }\end{array}$ \\
\hline $\mathrm{H} 7$ & Yes & $\begin{array}{l}\text { - They asked her if she is a foreigner; notice } \\
\text { something different in the accent }\end{array}$ & $x$ \\
\hline H8 & Yes & $\begin{array}{l}\text { - Only when she lived abroad; attracted } \\
\text { attention for being different }\end{array}$ & $\begin{array}{l}\text { Does not consider } \\
\text { it a negative } \\
\text { experience }\end{array}$ \\
\hline H9 & Yes & $\begin{array}{l}\text { - They told her that the accent was from the } \\
\text { city and when she moved to the rural area, } \\
\text { they told her that her accent had changed }\end{array}$ & $\begin{array}{l}\text { Does not consider } \\
\text { it a negative } \\
\text { experience }\end{array}$ \\
\hline
\end{tabular}




\begin{tabular}{|c|c|c|c|}
\hline $\mathrm{H} 10$ & No & No experiences reported. & $x$ \\
\hline $\mathrm{H} 11$ & No & $\begin{array}{l}\text { - Sometimes says phrases that people do not } \\
\text { understand }\end{array}$ & $\begin{array}{l}\text { Does not consider } \\
\text { it a negative } \\
\text { experience }\end{array}$ \\
\hline $\mathrm{H} 12$ & Yes & $\begin{array}{l}\text { - In Turrialba he uses usted more and in the } \\
\text { Central Valley he uses voS; when he changes } \\
\text { his form, they criticize him for the change. }\end{array}$ & $x$ \\
\hline
\end{tabular}

Table 7. Self-perception and experiences related to the way of speaking.

Table 8 shows the perception of speech of each speaker in the reading of the sentences according to one of the other participants in the study. In most cases, the speakers were perceived as members of the middle class of the GAM, and even in a couple of cases they were perceived as members of a higher socioeconomic group. The only exception was H11 on which the listener could not determine the social class based on their speech.

It is noteworthy that even though all the speakers have completed university education, most of them were perceived by the listeners as having barely a secondary education (7 cases). This perception of the educational level was found for both men and women of different ages, therefore we do not consider that this is an effect related to the gender of the speaker.

Another possible factor at play is the perceived age of the speaker. It was not possible to determine if this perception may be related to the perception of the speaker voice as that of a teenager. If such were the case, it is reasonable for listeners to assume that the highest educational level possible is secondary education. However, in the absence of data on the listener perception of age of the speaker it is not possible to determine if was factor is at play.

\begin{tabular}{lllll}
\hline Speaker & $\begin{array}{l}\text { Does the speech } \\
\text { reflect the middle } \\
\text { class of the GAM? }\end{array}$ & $\begin{array}{l}\text { Academic degree } \\
\text { of the speaker }\end{array}$ & $\begin{array}{l}\text { Socioeconomic } \\
\text { group }\end{array}$ & Listener \\
\hline $\mathrm{H} 1$ & Totally agree & Ill cycle of secondary & Middle & $\mathrm{H} 7$ \\
$\mathrm{H} 2$ & Agree & University & Middle & $\mathrm{H} 8$ \\
$\mathrm{H} 3$ & Agree & Un cycle of secondary & Middle & $\mathrm{H} 9$ \\
$\mathrm{H} 4$ & Totally agree & High & $\mathrm{H} 10$ \\
$\mathrm{H} 5$ & Totally agree & IV cycle of secondary & Middle & $\mathrm{H} 11$ \\
$\mathrm{H} 6$ & & IV cycle of secondary & Middle & $\mathrm{H} 12$
\end{tabular}




\begin{tabular}{|c|c|c|c|c|}
\hline $\mathrm{H} 7$ & Agree & University & High & $\mathrm{H} 1$ \\
\hline $\mathrm{H} 8$ & Totally agree & University & Middle & $\mathrm{H} 2$ \\
\hline $\mathrm{H} 9$ & Totally agree & IV cycle of secondary & Middle & $\mathrm{H} 3$ \\
\hline $\mathrm{H} 10$ & Agree & IV cycle of secondary & Middle & $\mathrm{H} 4$ \\
\hline $\mathrm{H} 11$ & $\begin{array}{l}\text { Neither agree nor } \\
\text { disagree }\end{array}$ & IV cycle of secondary & Middle & $\mathrm{H} 5$ \\
\hline 112 & Aaree & University & Middle & $\mathrm{H} 6$ \\
\hline
\end{tabular}

Table 8. Listener perception of the speakers reading sentences.

According to the results obtained and shown in Table 9, none of the allophones used by the speakers in the reading of sentences corresponds to the non-prestigious allophones mentioned by Quesada Pacheco (2000), in particular, the voiceless alveolar approximant as an allophone of the alveolar tap and assibilated variants of the trill. These results are consistent with the perception of the speakers as people belonging to a middle- or upperclass socioeconomic group. According to what was observed in the analysis of the speech in the answering of questions, some of the speakers presented isolated assibilated realizations of the rhotics. However, the assibilated realizations were not present in the reading of sentences, which corresponds with careful speech.

\begin{tabular}{|c|c|c|c|c|}
\hline Speaker & $\begin{array}{l}\text { Allophones } \\
\text { of alveolar tap } \\
\text { (before nasal) }\end{array}$ & $\begin{array}{l}\text { Allophones } \\
\text { of trill }\end{array}$ & $\begin{array}{l}\text { Academic degree } \\
\text { of the speaker }\end{array}$ & $\begin{array}{l}\text { Socioeconomic } \\
\text { group }\end{array}$ \\
\hline $\mathrm{H} 1$ & Ret & Fri & III cycle of secondary & Middle \\
\hline $\mathrm{H} 2$ & Ret & Apr & University & Middle \\
\hline H3 & $x$ & Fri & IV cycle of secondary & Middle \\
\hline $\mathrm{H} 4$ & Tap & Fri & University & High \\
\hline H5 & Tap & Tri & IV cycle of secondary & Middle \\
\hline $\mathrm{H} 6$ & $\mathrm{X}$ & Fri & IV cycle of secondary & Middle \\
\hline
\end{tabular}




\begin{tabular}{|c|c|c|c|c|}
\hline $\mathrm{H} 7$ & Ret & Fri & University & High \\
\hline H8 & Tap & Apr & University & Middle \\
\hline H9 & Tap & Apr & IV cycle of secondary & Middle \\
\hline $\mathrm{H} 10$ & Tap & Apr & IV cycle of secondary & Middle \\
\hline $\mathrm{H} 11$ & Tap & Apr & IV cycle of secondary & Middle \\
\hline $\mathrm{H} 12$ & Tap & Apr & University & Middle \\
\hline
\end{tabular}

Table 9. Comparison between predominant variants and external perception.

\section{CONCLUSIONS}

From the results obtained in the reading of sentences, we can conclude that the speakers belonging to the studied sample show allophonic realizations to the alveolar tap and alveolar trill consistent with those found in middle- or upper-class Costa Ricans. None of the variants observed by listeners in the reading of sentences corresponded to less prestigious variants and all the speakers were perceived as belonging to middle- or upper-class groups.

As has been mentioned before, social information influences listener perception, and as such, further developments of this research must take these social variables into account. Some of the social information that must be considered include perceptions of age, gender, origin, locations in which the speaker may have lived previously and trustworthiness of the speaker.

Despite these limitations, the present study provides a preliminary view into the current realizations of rhotics in Costa Rican middle-class individuals.

\section{ACKNOWLEDGEMENTS}

The authors wish to acknowledge the contributions of Prof. Ximena del Río Urrutia and Lander Arias in this work and in the corresponding presentation at the Linguistweets 2020 
conference. The authors also wish to thank the participants in this study. This work would not have been possible without their collaboration.

\section{REFERENCES}

CALVO SHADID, Annette. Variación fonética de /r/ y /r/ en el habla culta de San José. Revista de Filología y Lingüística, v. 21. n.1, p.115-134, 1995

CALVO SHADID, Annette; CASTILLO RIVAS, Jacqueline. Las actitudes lingüísticas en el español de San José, Costa Rica. Bergen Language and Linguistics Studies, v. 5, p.246-289, 2014.

CALVO SHADID, Annette; PORTILLA CHAVES, Mario. Variantes retroflejas de / $r$ / y / r/ en el habla culta de San José. Revista Káñina, v. 22, p. 81- 86, 1998.

CAMPBELL-KIBLER, Kathryn. Listener perceptions of sociolinguistic variables: the case of (ING). Dissertation (Doctorate in Linguistics) - Department of Linguistics, Stanford University, Palo Alto, United States of America, 2006.

FACEBOOK INC. WhatsApp Mountain View, California, 2020. Disponível em: <https://www.whatsapp.com/>. Acesso em: 18 jan. 2021

HESELWOOD, Barry; PLUG, Leendert; TICKLE, Alison. Assessing rhoticity using auditory, acoustic and psychoacoustic methods. Proceedings of Methods XIII: Papers from the International Conference on Methods in Dialectology, 2008

QUESADA PACHECO, Miguel Ángel. El español de Guanacaste. San José, Costa Rica: Editorial de la Universidad de Costa Rica, 1991.

QUESADA PACHECO, Miguel Ángel. Los fonemas del español de Costa Rica: aproximación dialectológica. Lexis, v. 20, n.1-2, p. 535-562, 1996

QUESADA PACHECO, Miguel Ángel. El español de América. San José, Costa Rica: Editorial Tecnológicas de Costa Rica, 2000

QUESADA PACHECO, Miguel Ángel. División dialectal de Costa Rica según sus hablantes. Dialectologia et Geolinguistica, v. 21, n. 1, p. 36-69, 2013

VÁSQUEZ CARRANZA, Luz Marina. On the phonetic realization and distribution of Costa Rican rhotics. Revista de Filología y Lingüística, v. 32, n. 2, p.291-309, 2006.

NIEDZIELSKI, Nancy. The effect of social information on the perception of sociolinguistic variables. Journal of Language and Social Psychology, v. 18, n. 1, p. 62-85, 1999. 